\title{
Purification and properties of a phosphate-irrepressible membrane-bound alkaline phosphatase from Zymomonas mobilis
}

\author{
Fatima Baoudene-Assali, Jacques Baratti and Gerard P. F. Michel* \\ Centre National de la Recherche Scientifique, Laboratoire de Chimie Bactérienne, 31 Chemin J. Aiguier, BP 71, \\ 13277 Marseille Cedex 9, France
}

(Received 20 July 1992; revised 24 September 1992; accepted 29 September 1992)

\begin{abstract}
The phosphate-irrepressible alkaline phosphatase of the ethanol-producing bacterium Zymomonas mobilis was solubilized from membranes by the cationic detergent $N$-cetyl- $N, N, N$-trimethylammonium bromide (CTAB) and purified by fast protein liquid chromatography. The purified enzyme was a monomeric protein of molecular mass $54 \mathrm{kDa}$, highly resistant to heat and to ionic strength. The alkaline phosphatase of growing $Z$. mobilis cells (ZAPase), remained active in the presence of an ethanol concentration as high as $100 \mathrm{~g} \mathrm{l}^{-1}$. However, in vitro, the stability of the purified ZAPase was severely affected at low ethanol concentration $\left(7.8 \mathrm{~g} \mathrm{l}^{-1}\right)$, showing the importance of the membrane environment in vivo. ZAPase differed from other bacterial alkaline phosphatases by having a higher affinity for the substrate 4-nitrophenylphosphate, a higher $K_{\mathrm{i}}$ for phosphate, only a partial reactivation by $\mathrm{Zn}^{2+}$ after EDTA inhibition, and a higher specific activity.
\end{abstract}

\section{Introduction}

Zymomonas mobilis, an obligately fermentative microorganism which converts glucose, fructose and sucrose to ethanol via the Entner-Doudoroff pathway (Swings \& De Ley, 1977), has been previously reported as containing a membrane-bound and phosphate-irrepressible alkaline phosphatase (Michel \& Baratti, 1989). Constitutive and phosphate-irrepressible alkaline phosphatases (APases) have been described in Capnocytophaga (Poirier \& Holt, 1983), Bacteroides ruminicola (Cheng \& Costerton, 1973) and Bacillus licheniformis (Hulett, 1987) but these enzymes were not found associated with membranes. Although not exceptional (Von Tigerstrom \& Stelmaschuk, 1986), the membrane location of bacterial APases is rather rare since these enzymes are generally detected in the periplasmic space of most of the Gramnegative bacteria studied (Bhatti et al., 1976; Cheng \& Costerton, 1973; Filloux et al., 1988; Garen \& Levinthal, 1960; Kobori et al., 1984; Poirier \& Holt, 1983; Roy et al., 1982). Thus, with respect to its mode of expression

\footnotetext{
*Author for correspondence. Tel. 911640 96; fax 91718914.

Abbreviations: APase, alkaline phosphatase; ZAPase, Zymomonas mobilis alkaline phosphatase; $p$-NPP, 4-nitrophenyl phosphate; CTAB, cetyltrimethylammonium bromide; DOC, sodium deoxycholate; OTAC, octadecyltrimethylammonium chloride; SLS, sodium laurylsarcosinate.
}

(absence of phosphate repression) and its location (membrane-bound), the enzyme of $Z$. mobilis (ZAPase) can be considered as atypical. A characteristic such as membrane location might reflect specific requirements in relation to the alcoholic environment of the bacterium. Little is known about phosphate metabolism in $Z$. mobilis. However, alkaline and acid phosphatase activities have been described in Z. mobilis CP4 (Pond et al., 1989) and an APase has been purified from Z. mobilis ZM4 by chromatography on multifunctional adsorbents (Reyes \& Scopes, 1991). This paper deals with the purification by fast protein liquid chromatography (FPLC) of a highly active ZAPase from detergentsolubilized membranes of the ZM1 and ZM4 strains of Z. mobilis.

\section{Methods}

Bacterial strains, and growth conditions. Zymomonas mobilis ZM1 (ATCC 10988) and ZM4 (ATCC 31821) were grown statically at $30^{\circ} \mathrm{C}$, in complex medium as previously described (Michel \& Baratti, 1989). Growth was monitored by measurement of optical density at $450 \mathrm{~nm}$.

Phosphatase assay. APase was assayed at $30^{\circ} \mathrm{C}$ in a reaction mixture containing $0.1 \mathrm{ml}$ enzyme extract and $0.9 \mathrm{ml} 0.1 \%$ (w/v) 4-nitrophenyl phosphate ( $p$ NPP) in $0.1 \mathrm{M}$-Tris/ $\mathrm{HCl} \mathrm{pH} \mathrm{8.0.} \mathrm{The} \mathrm{amount} \mathrm{of} \mathrm{substrate}$ hydrolysed per unit time was calculated from the absorbance of 4 nitrophenol liberated using a molar absorption coefficient of $1.62 \times$ $10^{4} \mathrm{M}^{-1} \mathrm{~cm}^{-1}$ at $410 \mathrm{~nm}$. One unit was defined as the amount of enzyme which liberates $1 \mu \mathrm{mol}$ nitrophenol $\mathrm{min}^{-1}$. The use of HEPES buffer instead of Tris buffer in the assay decreased activity by only $30 \%$, 
suggesting that transphosphorylation on Tris (Roy et al., 1982) was limited. Therefore, Tris buffer was used for the assay. APase activities at different $\mathrm{pH}$ values were determined according to Von Tigerstrom (1984).

Preparation of cell extracts. Cells grown in complex medium were centrifuged $\left(7000 \mathrm{~g}, 10 \mathrm{~min}, 4^{\circ} \mathrm{C}\right)$ washed in $10 \mathrm{~mm}$-Tris $/ \mathrm{HCl} \mathrm{pH} 7.4$ and resuspended in the same buffer after centrifugation. Cells were disrupted after passage through a French pressure cell (two passages at $294 \mathrm{MPa}$, one passage at $392 \mathrm{MPa}$ ) or ultrasonically disintegrated using a Branson Sonifier (three periods of $15 \mathrm{~s}$ at $45 \mathrm{~W}$, with $45 \mathrm{~s}$ intervals between periods). Membranes were recovered in the pellet after ultracentrifugation of the cell extract $\left(170000 \mathrm{~g}, 90 \mathrm{~min}, 4^{\circ} \mathrm{C}\right)$.

Protein assay. Proteins were assayed as described by Schaecterle \& Pollach (1975) with BSA as a standard. Detergent-treated samples were assayed after removal of the detergent according to Wessel \& Flugge (1984).

Solubilization of APase from $Z$. mobilis membranes. Membranes resuspended in $10 \mathrm{~mm}$-Tris $/ \mathrm{HCl} \mathrm{pH} 7.5$ were incubated with detergents (final concentration $0.5 \%, \mathrm{w} / \mathrm{v}$ ) for $30 \mathrm{~min}$ at $20^{\circ} \mathrm{C}$ under mild agitation. Treatment was carried out with anionic detergents (sodium lauryl sarcosinate and sodium deoxycholate), non-ionic detergents (Triton X-100, Triton X-114, Tween 80, Brij 35 and Nonidet P40), cationic detergents ( $N$-cetyl- $N, N, N$-trimethylammonium bromide, octadecyltrimethylammonium chloride) and a zwitterionic detergent ( $N$-dodecyl- $N, N$-dimethylammonio-3-propanesulphonate). Detergenttreated membranes were centrifuged $\left(100000 \mathrm{~g}, 90 \mathrm{~min}, 4^{\circ} \mathrm{C}\right)$ and the solubilized membrane components recovered in the supernatant.

Purification of membrane-bound APase. Z. mobilis cells were grown in a 20 litre fermenter containing 19 litres of complex medium $(100 \mathrm{~g}$ glucose $\left.1^{-1}\right)$. The membranes were obtained as described above after disruption in a French pressure cell, resuspended in $10 \mathrm{mM}$-Tris $/ \mathrm{HCl}$ pH 7.5 and treated for $1 \mathrm{~h}$ at $20^{\circ} \mathrm{C}$ with $1 \%$ (w/v) $N$-cetyl- $N, N, N$ trimethylammonium bromide (CTAB). The insoluble fraction was removed by ultracentrifugation $\left(100000 \mathrm{~g}, 90 \mathrm{~min}, 4^{\circ} \mathrm{C}\right)$ and the supernatant containing APase dialysed for $24 \mathrm{~h}$ at $4{ }^{\circ} \mathrm{C}$ against $10 \mathrm{~mm}-$ Tris $/ \mathrm{HCl}, 0.25 \%$ CTAB, pH 8.5 . The dialysed fraction was loaded on a Q-Sepharose column $(2.5 \mathrm{~cm} \times 40 \mathrm{~cm}$, filled with $160 \mathrm{ml}$ gel, Pharmacia) equilibrated with $10 \mathrm{mM}$-Tris $/ \mathrm{HCl}, 0.25 \% \mathrm{CTAB}, \mathrm{pH} 8.5$ and the adsorbed proteins eluted with a two-step $\mathrm{KCl}$ gradient, using an FPLC system (Pharmacia). The first gradient step $(0-0.5 \mathrm{M}-\mathrm{KCl})$ was carried out within $30 \mathrm{~min}$ and the second step $(0.5-1 \mathrm{M}-\mathrm{KCl})$ within $1 \mathrm{~h}$ (flow rate $\left.1 \mathrm{ml} \mathrm{min}^{-1}\right)$. Fractions $(1.4 \mathrm{ml})$ were collected. Fractions containing APase were pooled, dialysed for $24 \mathrm{~h}$ at $4{ }^{\circ} \mathrm{C}$ against $10 \mathrm{~mm}$ Tris $/ \mathrm{HCl}, 0.25 \%$ CTAB, pH 7.5 and applied to a Mono Q column $(0.5 \mathrm{~cm} \times 5 \mathrm{~cm}$, filled with $1 \mathrm{ml}$ gel, Pharmacia) equilibrated with $10 \mathrm{~mm}$-Tris $/ \mathrm{HCl}, 0.15 \% \mathrm{CTAB}, \mathrm{pH} 7.5$. The adsorbed proteins were eluted in $10 \mathrm{~mm}$-Tris/ $\mathrm{HCl}, 0.25 \% \mathrm{CTAB}$, pH 7.5 within $1 \mathrm{~h}$ using a linear $\mathrm{KCl}$ gradient ( 0 to $0.1 \mathrm{M}-\mathrm{KCl}$ in $10 \mathrm{~mm}$-Tris $/ \mathrm{HCl}, 0.25 \%$ CTAB, pH 7.5). Fractions of $0.6 \mathrm{ml}$ were collected. Fractions containing APase activity were pooled, concentrated on ultrafree-PF membranes (UFP1-LGC14, Millipore) and applied to a Superose 12 column $(1 \mathrm{~cm} \times 30 \mathrm{~cm}$, filled with $24 \mathrm{ml}$ gel, Pharmacia). Proteins were eluted with $100 \mathrm{~mm}$-Tris $/ \mathrm{HCl}, 0 \cdot 15 \%$ CTAB, $\mathrm{pH} 7 \cdot 5$. Elution of the proteins was monitored as absorbance at $280 \mathrm{~nm} ; 0.6 \mathrm{ml}$ fractions were collected and assayed for APase activity. Fractions containing APase activity were pooled and concentrated on ultrafree-PF membranes.

Substrate specificity. Determination of substrate specificity was carried out at $1 \mathrm{~mm}$ concentration with the following substrates: 4-nitrophenyl phosphate ( $p$ NPP), AMP, ATP, glucose 6-phosphate and fructose 6-phosphate. The amount of inorganic phosphate liberated by APase activity was determined according to Saheki $e t$ al. (1985).
Determination of kinetic parameters. The $K_{\mathrm{m}}$ was determined from Hanes plots (substrate concentration/velocity against substrate concentration) which were shown to give more precise results than Lineweaver-Burk plots. Substrate was added to the reaction mixture at the following concentrations: $0 \cdot 67,1 \cdot 34,2 \cdot 0,2 \cdot 7,6 \cdot 7,13 \cdot 4,20 \cdot 1,26 \cdot 8$, $33.5 \mu \mathrm{M}$. The $K_{1}$ for phosphate was determined from Dixon plots (1/velocity against inhibitor concentration). $\mathrm{KH}_{2} \mathrm{PO}_{4}$ was added to the reaction mixture at the following concentrations: $2 \cdot 5,1 \cdot 0,0 \cdot 5,0 \cdot 25,0 \cdot 1$ and $0.5 \mu \mathrm{M}$. Assays were carried out using three different substrate concentrations close to or above the $K_{\mathrm{m}}$ value $(2 \cdot 7 \mu \mathrm{M}-, 6.7 \mu \mathrm{M}$-, and $13.4 \mu \mathrm{M}-p \mathrm{NPP})$.

Polyacrylamide gel electrophoresis. One dimensional SDS-PAGE (10.5\%, w/v, acrylamide) and two-dimensional PAGE were performed according to Laemmli (1970) and O'Farrell (1975), respectively. APase staining on gels was carried out as described previously (Michel \& Baratti, 1989).

\section{Results}

\section{Enzyme solubilization}

Detergents of four different classes (anionic, neutral, cationic and zwitterionic) were tested for their ability to release APase from a $Z$. mobilis membrane preparation without affecting activity. In our experimental conditions, the enzyme was not solubilized by Triton X-100 and only low levels of unsedimentable APase were obtained after treatment with Tween 80 , Nonidet P40 and $N$-dodecyl- $N, N$-dimethyl-ammonio-3-propanesulphonate ( 3 to about $8 \%$ of the total activity) (Table 1 ). Sodium deoxycholate (DOC), Triton X-114 and Brij 35 were more efficient solubilizers since 34 to $47 \%$ of the total activity was released from membranes treated with these detergents (Table 1). By contrast, more than $80 \%$ of the APase activity was released by sodium laurylsarcosinate (SLS), $N$-cetyl- $N, N, N$-trimethylammonium

Table 1. Effectiveness of detergents in the solubilization of the APase of $Z$. mobilis

\begin{tabular}{|c|c|c|}
\hline Detergent & Charge & $\begin{array}{c}\text { Soluble } \\
\text { APase } \\
(\%)^{*}\end{array}$ \\
\hline None & 0 & ND \\
\hline Sodium laurylsarcosinate (SLS) & - & $81 \cdot 2$ \\
\hline Sodium deoxycholate (DOC) & - & $34 \cdot 4$ \\
\hline Triton $\mathrm{X}-100$ & 0 & ND \\
\hline Triton X-114 & 0 & $46 \cdot 9$ \\
\hline Tween 80 & 0 & $3 \cdot 0$ \\
\hline Brij 35 & 0 & $34 \cdot 4$ \\
\hline Nonidet P40 & 0 & $7 \cdot 9$ \\
\hline Cetyltrimethylammonium bromide (CTAB) & + & $87 \cdot 5$ \\
\hline $\begin{array}{l}\text { Octadecyltrimethylammonium chloride } \\
\text { (OTAC) }\end{array}$ & + & $82 \cdot 3$ \\
\hline $\begin{array}{l}\text { Dodecyldimethylammonio-3- } \\
\text { propanesulphonate }\end{array}$ & \pm & $4 \cdot 8$ \\
\hline
\end{tabular}

* Results are expressed as percentages of the activity recovered in the soluble fraction after treatment of membranes with detergents as described in Methods. ND, not detected. 
bromide (CTAB) and octadecyltrimethylammonium chloride (OTAC). Removal of the ionic detergent from the enzyme preparation by dialysis or replacement with Triton X-100 led to complete enzyme inactivation. The requirement of ionic detergents for enzyme solubilization suggested that in Z. mobilis, APase is bound through strong interactions to some components of the cell membrane. CTAB, the most efficient solubilizing agent, did not affect enzyme stability and therefore, it was selected for the purification procedure.

\section{Purification procedure}

APase from Z. mobilis ZM1 (ZAPase) was purified by FPLC from a membrane fraction solubilized with CTAB, using a procedure involving three chromatographic steps (Table 2). Treatment of a membrane fraction with $1 \%$ (w/v) CTAB resulted in a 7.6-fold purification, with an activity yield of $87 \%$. The soluble fraction was loaded on a Q-Sepharose column and the adsorbed proteins eluted with a two-step $\mathrm{KCl}$ gradient. ZAPase eluted at $0.75 \mathrm{M}$ $\mathrm{KCl}$ with a $100 \cdot 4$-fold purification (Fig. $1 a$, Table 2). The enzyme was further purified on a Mono $Q$ column and eluted with a linear $\mathrm{KCl}$ gradient $(0$ to $0.1 \mathrm{M})$ at $0.05 \mathrm{M}$ $\mathrm{KCl}$ (Fig. 1 b). The specific activity was increased 12 -fold compared to the previous step, with a yield of $54 \%$. The active fractions were pooled, concentrated by ultrafiltration and loaded onto a Superose 12 column. Proteins were separated into four major peaks and the activity recovered into the first eluted peak (Fig. 1c). The purification was achieved with an overall yield of $36.3 \%$ and the final purification factor was 8693-fold (Table 2). The specific activity of the enzyme $\left(89 \times 10^{4} \mathrm{IU} \mathrm{mg}^{-1}\right)$ differed considerably from that reported by Reyes \& Scopes (1991) ( $\left.37 \mathrm{IU} \mathrm{mg}^{-1}\right)$. Such a difference could be explained by the procedure used for enzyme solubilization. The ZAPase purified by Reyes \& Scopes (1991) was extracted from membranes by Triton X-100 treatment. In our hands, this neutral detergent was inefficient, and release of ZAPase from membranes with a good

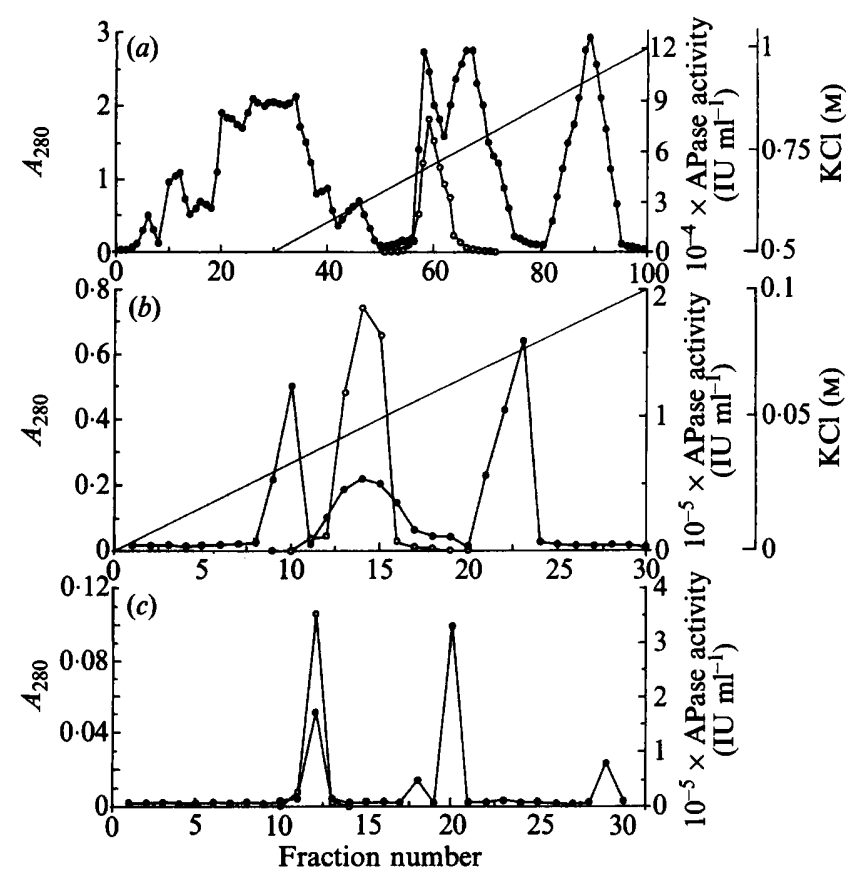

Fig. 1. Elution profiles of APase from Q Sepharose (a), Mono $Q(b)$ and Superose $12(c)$ columns. The samples loaded were as described in Methods.,$A_{280} ; \bigcirc$, APase activity;,$- \mathrm{KCl}$ gradient.

efficiency ( $80 \%$ of the total activity) was only achieved by using ionic detergents. On the other hand, the specific activity of the ZAPase was considerably higher than that described for the enzymes of Lysobacter enzymogenes (438 IU mg ${ }^{-1}$ ) (Von Tigerstrom \& Stelmaschuk, 1986), Escherichia coli (1500 $\mathrm{IU} \mathrm{mg}^{-1}$ ) (Torriani, 1966) and Micrococcus sodonensis (82 IU mg ${ }^{-1}$ ) (Glew \& Heath, 1971). The high specific activity of ZAPase could also be explained by the presence of CTAB simulating the native environment of the enzyme in the membrane. However, ZAPase was shown to be a minor protein in Z. mobilis, since it accounted for only $0.004 \%$ of total proteins ( $0.008 \%$ of membrane proteins). Z. mobilis APase was also purified from strain ZM4 with almost identical results (not shown). Thus, although present in very low

Table 2. Purification of the APase from $Z$. mobilis ZMI

\begin{tabular}{lccccc}
\hline \hline & \multicolumn{2}{c}{ Total amount of: } & & & \\
\cline { 2 - 3 } $\begin{array}{l}\text { Source } \\
\text { of fraction }\end{array}$ & $\begin{array}{c}\text { Enzyme } \\
\left(10^{-3} \times \text { units }\right)\end{array}$ & $\begin{array}{c}\text { Protein } \\
(\mathrm{mg})\end{array}$ & $\begin{array}{c}\text { Sp. act } \\
\left(\text { units } \mathrm{mg}^{-1}\right)\end{array}$ & $\begin{array}{c}\text { Yield } \\
\%\end{array}$ & $\begin{array}{c}\text { Purification } \\
\text { (-fold) }\end{array}$ \\
\hline Crude extract & 978 & 9310 & 105 & 100 & 1 \\
Membranes & 850 & 4600 & 185 & 87 & $1 \cdot 8$ \\
CTAB-soluble & 851 & 1070 & 795 & 87 & $7 \cdot 6$ \\
$\begin{array}{l}\text { extract } \\
\text { Q-Sepharose }\end{array}$ & 686 & 65.0 & 10550 & 70 & $100 \cdot 4$ \\
Mono Q & 529 & $4 \cdot 30$ & 123000 & 54 & 1190 \\
Superose 12 & 355 & $0 \cdot 40$ & 887500 & 36 & 8690 \\
\hline \hline
\end{tabular}




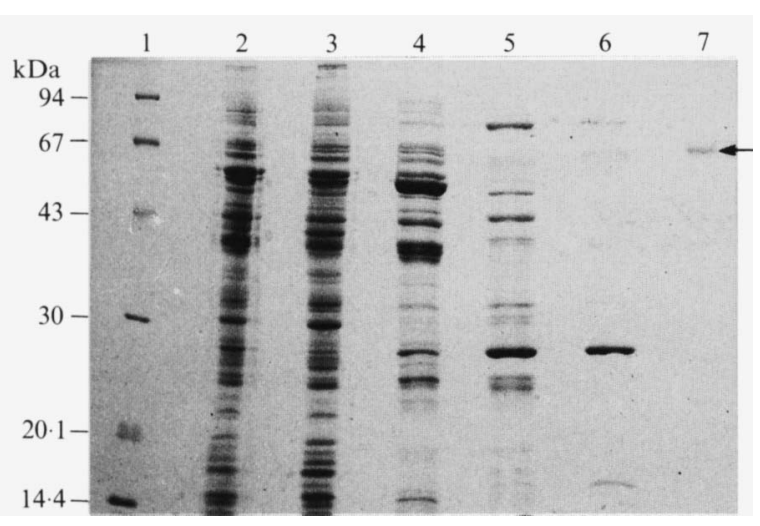

Fig. 2. Purity of the enzyme preparation from strain ZM1. Proteins were analysed by SDS-PAGE at different steps of the purification procedure. Lane 1, molecular mass standards; lane 2, crude extract; lane 3, membranes; lane 4, CTAB-soluble fraction; lane 5, Q Sepharose eluate; lane 6, Mono Q eluate; lane 7, Superose 12 eluate. ZAPase is indicated by an arrow.

amounts in cells, Z. mobilis APase displayed a high catalytic activity.

\section{Homogeneity and molecular mass}

Protein fractions were analysed by SDS-PAGE at different steps of the purification procedure. Active fractions eluted from the Superose 12 column contained only one protein of $60 \mathrm{kDa}$ as indicated by SDS-PAGE (Fig. 2). This molecular mass is slightly different from that previously reported after activity staining $(56 \mathrm{kDa})$ (Michel \& Baratti, 1989). However, it should be pointed out that protein denaturation was only partial when proteins were stained for phosphatase activity on gels. Indeed, heat treatment and reducing agent were omitted. Moreover, it cannot be excluded that trace amounts of the cationic detergent CTAB still remained associated with the protein, even after dialysis, and affected electrophoretic mobility in the SDS system. The molecular mass of the native ZAPase was determined from the elution pattern after calibration of the Superose 12 column with standard proteins. It was estimated to be about $54 \mathrm{kDa}$. This result is in agreement with the molecular mass $(55 \mathrm{kDa}$ ) of the APase purified by Reyes \& Scopes (1991). However, as emphasized by Tanford \& Reynolds (1976), concern is sometimes expressed when the molecular mass of a native protein is determined in the presence of an ionic detergent. Indeed, although ZAPase purified in the presence of CTAB remained in a native state as shown by activity assay, a dissociation into subunits cannot be excluded. Nevertheless, retention of activity in the presence of detergent is consistent with the absence of disruption of interpeptide bonds important for primary function (Tanford \& Reynolds, 1976). Thus, by comparison with the molecular mass on
SDS-PAGE, and with the results obtained by Reyes \& Scopes (1991), it could be concluded that the APase of $Z$. mobilis was most probably a monomeric protein. Twodimensional PAGE analysis of the purified enzyme (data not shown), showed several isoforms which are consistent with the results previously reported (Michel \& Baratti, 1989). Very similar results were obtained with the APase purified from strain ZM4: the same molecular mass on SDS-PAGE and Superose 12 column, and presence of isoforms revealed by two-dimensional PAGE.

\section{Effect of $p H$, temperature and ionic strength on activity}

The effect of $\mathrm{pH}$ on ZAPase activity was studied according to Von Tigerstrom (1984). Activity on $p$ NPP was observed between $\mathrm{pH} 6$ and $\mathrm{pH} 11$ and was maximal at $\mathrm{pH} 8$. These results are in agreement with the $\mathrm{pH}$ range reported for membrane-bound or periplasm-located APases in other bacteria (Garen \& Levinthal, 1960; Vinter et al., 1987; Von Tigerstrom, 1984). However, the optimum $\mathrm{pH}$ for APase activity found in the present work ( $\mathrm{pH} 8)$, differed from that reported by Reyes \& Scopes (1991) (pH 9).

ZAPase activity was assayed in a temperature range from $4{ }^{\circ} \mathrm{C}$ to $60^{\circ} \mathrm{C}$. Activity increased with temperature up to $40^{\circ} \mathrm{C}$ and decreased upon further heating.

The APase of Z. mobilis was shown to be particularly resistant to ionic strength and remained fully active when the assay mixture contained up to $2.5 \mathrm{M}-\mathrm{KCl}$ (the highest $\mathrm{KCl}$ concentration tested).

\section{Stability}

Incubation of the enzyme for $1 \mathrm{~h}\left(30^{\circ} \mathrm{C}\right)$ at different $\mathrm{pH}$ values before the assay showed that ZAPase was fully stable in the $\mathrm{pH}$ range from 6 to 9 . The purified enzyme was stable at $-20^{\circ} \mathrm{C}$ and around $+20^{\circ} \mathrm{C}$ for 4 months, but its activity decreased by $40 \%$ after 2 months and by $55 \%$ after 4 months at $4{ }^{\circ} \mathrm{C}$. Enzyme inactivation at $4{ }^{\circ} \mathrm{C}$ was most probably due to the gradual crystallization of the solubilizing agent CTAB at this temperature. Furthermore, incubation of the enzyme at high temperatures showed that ZAPase remained stable for at least $1 \mathrm{~h}$ at $60{ }^{\circ} \mathrm{C}$, but further increase of temperature caused inactivation. Above $70^{\circ} \mathrm{C}$, the enzyme was completely inactivated. This result was consistent with the heat resistance of other APases, particularly those of Lysobacter enzymogenes (Von Tigerstrom, 1984; Von Tigerstrom \& Stelmaschuk, 1986), Micrococcus sodonensis (Glew \& Heath, 1971) and E. coli (Garen \& Levinthal, 1960).

The effect of $\mathrm{pH}$ and temperature on both activity and stability of APase from strain ZM4 was identical to that observed for the enzyme from strain ZM1. 


\section{Table 3 Effect of inhibitors on APase activity}

APase was incubated for $15 \mathrm{~min}$ at $30^{\circ} \mathrm{C}$ in the presence of inhibitors at indicated concentrations and assayed. Results are expressed as percentages relative to the control $(100 \%=$ $3.5 \times 10^{5} \mathrm{IU} \mathrm{ml}^{-1}$ ).

\begin{tabular}{lccc}
\hline \hline & \multicolumn{3}{c}{ Activity (\%) } \\
\cline { 2 - 4 } Inhibitor concn of: \\
\cline { 2 - 4 } & $0 \cdot 1 \mathrm{mM}$ & $1 \mathrm{mM}$ & $5 \mathrm{mM}$ \\
\hline Sodium arsenate & 33 & $10 \cdot 9$ & 0 \\
Potassium phosphate & 100 & $71 \cdot 8$ & $38 \cdot 7$ \\
Potassium cyanide & $77 \cdot 8$ & $39 \cdot 6$ & 0 \\
EDTA & $62 \cdot 5$ & 0 & 0 \\
$\beta$-Hydroxyquinoline & $85 \cdot 6$ & $65 \cdot 1$ & $13 \cdot 5$ \\
Iodoacetate & $85 \cdot 5$ & $79 \cdot 1$ & $73 \cdot 5$ \\
$\beta$-Hydroxymercuribenzoate & $85 \cdot 9$ & 83 & $79 \cdot 4$ \\
L-Cysteine & 100 & $93 \cdot 2$ & $60 \cdot 4$ \\
$\beta$-Mercaptoethanol & 100 & 100 & 100 \\
\hline \hline
\end{tabular}

\section{Sensitivity to inhibitors}

The stability of ZAPase activity was tested in the presence of various inhibitors of enzyme activity. Potassium phosphate, potassium cyanide, sodium arsenate and especially EDTA (in increasing order) were the most powerful inhibitors studied, and their effect was concentration-dependent (Table 3). Activity was not greatly affected by reducing agents such as $\beta$-mercaptoethanol and L-cysteine. This result was quite surprising since in a previous study, ZAPase activity was shown to be detected on gels, after SDS-PAGE, only when the usual treatment with reducing agents was omitted (Michel \& Baratti, 1989). These contradictory results can be explained by the action of SDS on APase, exposing masked disulphide bonds to inhibitors. Furthermore, the enzyme activity was not significantly affected by thiolgroup inhibitors such as $p \mathrm{HMB}$ and iodoacetate, suggesting that thiol groups might not be essential for activity.

On the other hand, ethanol $\left(31.6 \mathrm{~g}^{-1}\right)$ suppressed ZAPase activity. Incubation of the enzyme in the presence of $7.8 \mathrm{~g}$ ethanol $1^{-1}$ for $1 \mathrm{~h}$ resulted in a $50 \%$ inhibition of activity (data not shown). These results were particularly surprising since cellular APase was shown to retain activity in cultures producing much higher ethanol concentrations $\left(50-100 \mathrm{~g}^{-1}\right)$, in vivo (data not shown). The highest resistance of ZAPase to ethanol in growing cells could be related to the membrane location of the enzyme.

\section{Effect of metal ions on activity}

ZAPase was inactivated by $1 \mathrm{~mm}$-EDTA and its reactivation studied by adding various metal ions $(5 \mathrm{mM}$ concn). Addition of $\mathrm{MnCl}_{2}, \mathrm{CuSO}_{4}, \mathrm{CoCl}_{2}, \mathrm{BaCl}_{2}, \mathrm{NiCl}_{2}$, $\mathrm{NaCl}$ and $\mathrm{KCl}$ did not cause any reactivation of the enzyme. In the presence of $\mathrm{MgCl}_{2}$ and $\mathrm{CaCl}_{2} 4 \%$ of the initial activity was recovered. $\mathrm{ZnCl}_{2}$ was the most potent activator but only $25 \%$ of the initial ZAPase activity could be recovered (data not shown). By comparison, $66 \%$ of the APase activity of Lysobacter enzymogenes (Von Tigerstrom \& Stelmaschuk, 1986) and $82 \%$ of that of a Pseudomonas sp. (Kobori \& Taga, 1980) was recovered after addition of $0.05 \mathrm{mM}$ and $0.5 \mathrm{mM}-\mathrm{ZnCl}_{2}$ respectively, to an EDTA-treated enzyme preparation. Similarly, EDTA-inactivated APase from Micrococcus sodonensis recovered $90 \%$ of its initial activity when further treated with $1 \mathrm{~mm}-\mathrm{Ca}^{2+}$ (Glew \& Heath, 1971).

\section{Substrate specificity}

The activity of the purified ZAPase was assayed in the presence of different phosphate esters. ZAPase exhibited a broad substrate specificity. Results (expressed as percentages relative to $p$ NPP) showed that the highest activities were obtained with $p$ NPP (100), ATP (95.8 \pm 13.2) and AMP (82.8 $\pm 15 \cdot 7)$, while glucose 6-phosphate $(19 \cdot 3 \pm 8.0)$ and fructose 6-phosphate $(23.6 \pm 6.9)$ were hydrolysed to a lesser extent.

\section{Kinetic constants}

ZAPase exhibited a very high catalytic activity since the $k_{\text {cat }}$ was estimated to be about $50 \times 10^{6} \mathrm{~min}^{-1}$. Kinetic study of the purified enzyme showed a $K_{\mathrm{m}}$ for $p$ NPP hydrolysis of $5 \pm 2 \times 10^{-6} \mathrm{M}$. This $K_{\mathrm{m}}$ value was lower than those found in E. coli $\left(1.2 \times 10^{-5} \mathrm{M}\right)$ (Garen \& Levinthal, 1960), L. enzymogenes $\left(0.56-3.4 \times 10^{-4} \mathrm{M}\right)$ (Von Tigerstrom \& Stelmaschuk, 1986) or Vibrio cholerae $\left(2.2 \times 10^{-4} \mathrm{M}\right)$ (Roy et al., 1982), showing a greater affinity for this substrate. Competitive inhibition by phosphate was observed, with the inhibition constant $\left(K_{\mathrm{i}}=2 \pm 0.2 \times 10^{-4} \mathrm{M}\right)$ higher than for the enzyme from E. coli $\left(K_{\mathrm{1}}=3.8 \times 10^{-6} \mathrm{M}\right)($ Garen \& Levinthal, 1960) or Vibrio cholerae $\left(K_{\mathrm{1}}=3 \cdot 3 \times 10^{-5} \mathrm{M}\right)$ (Roy et al., 1982).

\section{Discussion}

The alkaline phosphatases from Z. mobilis ZM1 and ZM4 (ZAPases) were found to be identical on the basis of molecular mass, $\mathrm{pH}$ optimum, and the effects of temperature, inhibitors, metal ions and ionic strength.

Under the conditions used, the phoA gene was not highly expressed in $Z$. mobilis, since ZAPase only accounts for $0.004 \%$ of the cellular proteins of this bacterium. Like most of the APases described, the APase of $Z$. mobilis was fully active at $\mathrm{pH} 8$ and was inhibited by the cation chelator EDTA. However, in comparison with the APases of other micro-organisms, the purified enzyme exhibits a higher specific activity, only a partial 
renaturation by $\mathrm{ZnCl}_{2}$ after EDTA treatment and a lower sensitivity to inhibition by phosphate. Furthermore, during growth of $Z$. mobilis, ZAPase remained active in spite of the high ethanol concentrations produced. The relative ineffectiveness of this alcohol in causing inhibition of activity in vivo contrasts markedly with the sensitivity of the purified enzyme to ethanol in vitro. These results suggest that ZAPase shows some specificities (e.g. membrane location) which could be required for the adaptation of the micro-organism to an alcoholic environment.

Our results also indicated that in both ZM1 and ZM4 strains, the purified ZAPase was a monomeric protein exhibiting high stability in the presence of CTAB. It accounted for the main phosphate-irrepressible APase activity present in these strains. Indeed, except for isoenzymes, no other APase could be further detected or purified. It has been reported that two different structural genes encoding, respectively, a dimeric and a monomeric APase were present in Bacillus subtilis (Hulett et al., 1990). On the other hand, studies on Z. mobilis CP4 (Pond et al., 1989) revealed four APase activities including a major phosphate-repressible APase. Recently, Reyes \& Scopes (1991) reported the purification of an APase from ZM4 using multifunctional adsorbents. These authors found two forms (ALP-1 and ALP-2) of APase which may differ in the amount of attached neutral lipids or the detergent Triton X-100 originating from the extraction. The ALP-2 form was purified and some of of its properties reported. However, ALP-2 was not shown to be identical to the ZAPase obtained using our purification procedure. Indeed, although the two enzymes exhibited a similar molecular mass ( 55 and 54 $\mathrm{kDa}$, respectively), their $\mathrm{pH}$ optimum, their substrate specificity and their specific activity were not identical.

On the other hand, the chemical composition of the detergent used for ZAPase solubilization seemed to be more important than the ionic charge, since OTAC and CTAB (cationic) were as active as SLS (anionic). Moreover, DOC (anionic) and dodecyldimethylammonio-3-propanesulphonate (zwitterionic) were not shown to be efficient solubilizing agents (especially the latter). The importance of the chemical composition of the detergent was also observed using uncharged compounds. Indeed, some of the neutral detergents used solubilized up to $47 \%$ of the total ZAPase (Triton X114), while others showed a poor effectiveness (Nonidet P40, Tween 80 and Triton X-100). The result obtained with Triton X-100 was particularly surprising since it contrasted with the effectiveness of this detergent on APase solubilization from Z. mobilis membranes (Reyes $\&$ Scopes, 1991). However, neutral detergents are known to be less efficient than ionic detergents in the ability to break protein interactions. It cannot be excluded that in our experimental conditions, disruption of interactions between ZAPase and other membrane components required more specific solubilizing agents than Triton $\mathrm{X}-100$.

Thus, the differences observed between our results and those obtained by Pond et al. (1989) on the one hand, and Reyes \& Scopes (1991) on the other, could be related either to strain specificities or to the experimental procedures used. Although we did not detect another form of APase in addition to the enzyme described in this work, it cannot be excluded that several forms of APase exist in $Z$. mobilis.

Mrs M. Cigna and F. Boussand are thanked for their technical assistance.

\section{References}

Bhatti, A. R., De Voe, I. W. \& Ingram, J. M. (1976). The release and characterization of some periplasm-located enzymes of Pseudomonas aeruginosa. Canadian Journal of Microbiology 22, 1425-1429.

Cheng, K. J., \& Costerton, J. N. (1973). Localization of alkaline phosphatase in three Gram-negative rumen bacteria. Journal of Bacteriology 116, 424-440.

Filloux, A., Bally, M., Soscia, C., Murgier, M. \& Lazdunski, A. (1988). Phosphate regulation in Pseudomonas aeruginosa: cloning of the alkaline phosphatase gene and identification of $p h o B$ and $p h o R$ like genes. Molecular and General Genetics 212, 510-513.

Garen, A. \& Levinthal, C. (1960). A fine structure genetic and chemical study of the enzyme alkaline phosphatase of $E$. coli. I. Purification and characterization of alkaline phosphatase. Biochimica et Biophysica Acta 38, 470-483.

Glew, R. H. \& Heath, E. C.(1971). Studies on the extracellular alkaline phosphatase of Micrococcus sodonensis. I. Isolation and characterization. Journal of Biological Chemistry 246, 1556-1565.

HuletT, F. M. (1987). Alkaline phosphatase from Bacillus licheniformis: proteins and genes. In Phosphate Metabolism and Cellular Regulation in Microorganisms, pp. 43-48. Edited by A. TorrianiGorini, F. G. Rothman, S. Silver, A. Wright \& E. Yagil. Washington DC: American Society for Microbiology.

Hulett, F. M., Bookstein, C. \& Jensen, K. (1990). Evidence for two structural genes for alkaline phosphatase in Bacillus subtilis. Journal of Bacteriology 172, 735-740.

KOBORI, H. \& TAGA, N. (1980). Extracellular alkaline phosphatase from marine bacteria: purification and properties of extracellular phosphatase from a marine Pseudomonas sp. Canadian Journal of Microbiology 26, 833-838.

Kobori, H., Sullivan, C. W. \& Shizuya, H. (1984). Heat-labile alkaline phosphatase from antartic bacteria: rapid $5^{\prime}$ end-labeling of nucleic acids. Proceedings of the National Academy of Sciences of the United States of America 81, 6691-6695.

LAEMMLI, U. K. (1970). Cleavage of structural proteins during the assembly of the head of bacteriophage T4. Nature, London 227, 680-685.

Michel, G. P. F. \& Baratti, J. (1989). Phosphate-irrepressible alkaline phosphatase of Zymomonas mobilis. Journal of General Microbiology 135, 453-460.

O'Farrell, P. H. (1975). High resolution two dimensional electrophoresis of proteins. Journal of Biological Chemistry 250, 4007-4021.

PoIRIER, T. P. \& HolT, S. C. (1983). Acid and alkaline phosphatases of Capnocytophaga species. I. Production and cytological localization of the enzymes. Canadian Journal of Microbiology 29, 1350-1360.

Pond, J. L., Eddy, C. K., Mackenzie, K. F., Conway, T., Borecki, D. J. \& Ingram, L. O. (1989). Cloning, sequencing and characterization of the principal acid phosphatase, the pho $C^{+}$product from Zymomonas mobilis. Journal of Bacteriology 171, 767-774.

REYES, L. B. \& SCOPES, R. K. (1991) The use of multifunctional 
adsorbents to purify membrane-bound phosphatases from Zymomonas mobilis. Bioseparation 2, 137-146.

RoY, N. K., Gosh, R. K. \& DAS, J (1982). Monomeric alkaline phosphatase of Vibrio cholerae. Journal of Bacteriology 150, 1033-1039.

SaheKI, S., Takeda, A. \& Shimazu, T. (1985). Assay of inorganic phosphate in the mild $\mathrm{pH}$ range, suitable for measurement of glycogen phosphorylase activity. Analytical Biochemistry 148, 277281.

Schaecterle, G. R. \& Pollach, R. L. (1975). A simplified method for the quantitative assay of protein in biological material. Analytical Biochemistry 51, 654-655.

Swings, J. \& DE LEY, J. (1977). The biology of Zymomonas. Bacteriological Reviews 41, 1-46.

TANFORD, C. \& REYNOLDS, J. A. (1976). Characterization of membrane proteins in detergent solutions. Biochimica et Biophysica Acta 457, 133-170.
TORRIANI, A. (1966). Alkaline phosphatase from Escherichia coli. In Procedures in Nucleic Acid Research, pp. 224-235. Edited by G. L. Cantoni \& D. R. Davis. London: Harper \& Row.

VINTER, V., SMID, F. \& SMRCKova, I. (1987). Factors influencing the activity of cellular alkaline phosphatase during growth and sporulation of Bacillus cereus. Folia Microbiologica 32, 89-95.

VON TIgERSTrom, R. G. (1984). Production of two phosphatases by Lysobacter enzymogenes and purification and characterization of the extracellular enzyme. Applied and Environmental Microbiology 47, 693-698.

Von Tigerstrom, R. G. \& StelmaschuK, S. (1986). Purification and characterization of the outer membrane associated alkaline phosphatase of Lysobacter enzymogenes. Journal of General Microbiology 132, 1379-1387.

WESSEL, D. \& FlugGe, U. I. (1984). A method for the quantitative recovery of protein in dilute solution in the presence of detergents and lipids. Analytical Biochemistry 138, 141-143. 